\title{
Tenofovir disoproxil fumarate reduce incidence of HCC development in CHB- patients with compensated cirrhosis
}

\author{
Ping Zhang, Qingli Liu, Mei Yuan and Lina Wang*
}

\begin{abstract}
Background: The impact of different anti-virus regimens on prognosis of Chronic hepatitis B (CHB) related cirrhosis remains to be explored. We aim to investigate whether CHB-related HCC patients receiving nucleoside analogue regimen or not have a different prognosis.

Methods: Two hundred forty-two CHB-related compensated cirrhosis patients were attributed into groups regarding their anti-virus regimens containing tenofovir disoproxil fumarate (TDF) or not. The results of two groups were reviewed and investigated. The probability of hepatocellular carcinoma (HCC) development among each group were analyzed and compared.

Results: Two hundred forty-two CHB-related compensated cirrhosis patients from 2008 June to 2011 December were included in our study. One hundred twenty-seven patients received anti-virus regimen containing TDF and 115 patients received anti-virus regimen without TDF. Child-Pugh score, alanine aminotransferase (ALT), total bilirubin level, status of hepatitis B e antigen ( $\mathrm{HBeAg}$ ) and serum HBV DNA level were compared between groups. The cumulative probability of HCC development in TDF-contained group were significantly lower than it in non-TDF-contained group $(p<0.05)$. Multi-variant analysis indicated that TDF-containing regimen treatment was significantly associated with lower probability of HCC development, (hazard ratio, 0.18 ; $95 \%$ confidence interval range, $0.07-0.45, p<0.05$ ).
\end{abstract}

Conclusion: Anti-virus regimen containing TDF benefits for the prognosis of CHB-related liver cirrhosis patients.

Keywords: Tenofovir, Chronic hepatits B, Hepatocellular carcinoma, Cirrhosis, Nucleus(t)ide analogues

\section{Background}

Hepatocellular carcinoma (HCC) is among the most common malignancies of high morbidity and mortality, especially in China [1, 2]. Chinese HCC patients account for the majority of HCC-related mortality in the world [1-4]. Factors associated with the development of HCC include: hepatitis $C$ virus infection, alcholic hepatic diseases, smoking and et al., among which chronic hepatits $\mathrm{B}(\mathrm{CHB})$ infection is highly related to HCC development [5-12]. CHB-related liver cirrhosis and HCC patients is predominant Chinese HCC patients, as hepatits B virus (HBV) infection is highly prevalent in China [13, 14].

Serum HBV-DNA level is a key predictor for liver cirrhosis and it has been proved to correlated to cirrhosis

\footnotetext{
* Correspondence: linawang1234@126.com

Clinical laboratory, the sixth people's hospital of Qingdao, Qingdao 266000 Shandong, China
}

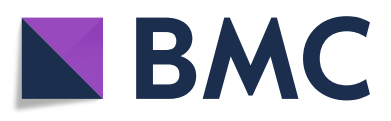

(c) The Author(s). 2018 Open Access This article is distributed under the terms of the Creative Commons Attribution 4.0 International License (http://creativecommons.org/licenses/by/4.0/), which permits unrestricted use, distribution, and reproduction in any medium, provided you give appropriate credit to the original author(s) and the source, provide a link to the Creative Commons license, and indicate if changes were made. The Creative Commons Public Domain Dedication waiver (http://creativecommons.org/publicdomain/zero/1.0/) applies to the data made available in this article, unless otherwise stated. replication to liver cirrhosis and $\mathrm{HCC}$ in $\mathrm{CHB}$. has been determined in several studies [16-18]. Thus, sustained suppression of HBV replication is regarded as critical to reduce liver cirrhosis or HCC progression [19]. Nucleos(t)ide analogues (NAs) have been determined to be highly effective for suppressing HBV replication [20], as well as regression of cirrhosis and reduction of HCC incidence [19, 21-23].

Surgical resection is still regarded as main curative therapy for localized HCC for it may provide probability of disease-free survival in HCC patients [24]. Sustained HBV replication has strong association with HCC recurrence in CHB-related HCC patients after surgery, so anti-HBV treatment is nessarry for CHB-related HCC patients [25]. It has been reported that NAs can provide 
additional benefits for $\mathrm{CHB}$-related $\mathrm{HCC}$ patients receiving local treatment, including hepatic resection [26-28].

Although both monotherapy or combination regimen of NAs have been proved to be effective in CHB-related HCC patients [26-28], it remains to be explored that whether there is any discrepancy among each regimen regarding their potential benefits in CHB-related compensated cirrhosis. Recently, it is reported that nucleutide analogues, rather than nucleuside analogues can induce the expression of IFN- $\lambda$ [29], which remind us whether there would be any difference regarding the prognosis of CHB-related compensated cirrhosis patients with different NAs regimens. Thus, we designed a retrospective cohort study to explore the potential difference among CHB-related cirrhosis patients with different NAs regimens.

\section{Methods}

\section{Patients and study design}

All CHB patients were diagnosed with compensated liver cirrhosis and received anti-HBV treatment in sixth people's hospital of Qingdao (Shandong, China). Inclusion criteria were: (1) Diagnosed as HBV infection with compensated liver cirrhosis; (2)Child-Pugh scoring $\leq 9$; (3) Valid clinical characteristics and laboratory outcomes. The exclusion criteria were: (1)Hepatocellular carcinoma; (2)HCV and HDV co-infection; (3)Alcoholic hepatic diseases; (4)Schistosomiasis; (5)Invalid clinical characteristics and laboratory outcomes; (6)Anti-virus regimen switching from non-TDF containing to TDF containing vice versa or received interferon treatment. Three hundred forty-seven patients were recruited into this retrospective study and 94 patients were excluded due to HCV co-infection $(n=12)$ and HDV co-infection $(n=11)$, alcoholic hepatic diseases $(n=6)$, schistosomiasis $(n=4)$, invalid data $(n=6)$, regimen switching due to virologic breakthrough $(n=36)$, interferon treatment $(n=$ $10)$ and lost $(n=20)$. The final patients included in this study were 242 .

This study was conducted under compliance with the Declaration of Helsinki and were approved by the Human Ethics Committee of sixth people's hospital of Qingdao.

\section{Diagnosis}

All patients were histologically confirmed with cirrhosis using specimen from liver biopsy or contrast-enhanced CT. HBV infection were diagnosed with positive serum viral marker and elevated serum HBV-DNA level $(>1000$ copies/mL during two consecutive detection). Quantification of serum HBV DNA was measured by real-time quantitative PCR assay with Roche LightCycler (Roche Diagnostics, Basel, Switzerland) and suitable 2reagents (PG Biotech, Shenzhen, China), of which the lower limit of quantification is 1000 copies $/ \mathrm{mL}$ and the linear range was between 1120 and $6.69 \log$ copies $/ \mathrm{mL}$. Contrastenhanced CT, ultrasonography or liver biopsy were conducted to screen HCC recurrence during follow-up. Child-Pugh scoring was applied for consideration of prognosis as previously reported [30].

\section{HBV treatment}

TDF-containing regimen included TDF monotherapy $(n=$ $13)$ or combined with lamivudine (LAM) $(n=95)$ and entecavir (ETV) $(n=19)$. Non-TDF containing regimen included LAM $(n=42)$, ETV $(n=61)$ or telbivudine (LdT) $(n$ $=12$ ) monotherapy. The dosage of NAs in all patients were $300 \mathrm{mg}$ per day for TDF, $100 \mathrm{mg}$ per day for LAM, $0.5 \mathrm{mg}$ per day for ETV and $600 \mathrm{mg}$ per day for LdT. In non-TDF containing group, 11 patients receiving LAM and 12 patients receiving LdT were switch to ETV due to virologic breakthrough.

\section{Statistics}

Continuous variables were expressed as mean \pm SD with normal distribution and median (range) without normal distribution. The comparison of continuous variables with or without normal distribution was analyzed with Student $t$ test and Wilcoxon rank test, respectively. Chi-square and Fisher's test were applicated for analysis of categorical variables. $p<0.05$ was regarded as statistically significant. The univariate analysis were conducted through Kaplan-Meier statistics and Log-rank test. Multivariate analysis was assessed with Cox regression test. Variables with $p<0.05$ were employed into the Cox regression model. $p<0.05$ was considered as statistically significant. Statistics analysis was conducted with SPSS (version 16.0, SPSS Inc., Chicago, IL, USA) software package. Figures were made with GraphPad Prism 5 software.

\section{Results}

The baseline characteristics

$242 \mathrm{CHB}$ patients with compensated cirrhosis were attributed to TDF-containing group $(n=127)$ and nonTDF-containing group $(n=115)$ regarding their antivirus regimen. The average age of TDF-containing group and non-TDF-containing group were $50 \pm 12$ and $50 \pm$ 10 , respectively. Male patients were predominant in both groups: TDF-containing group $(n=114,89.8 \%)$ and non-TDF-containing group $(n=98,85.2 \%)$. Median total bilirubin was 16.1 and $14.4 \mu \mathrm{mol} / \mathrm{L}$ in TDF-containing group and non-TDF-containing group, respectively. The percentage of patients with Child-Pugh scoring A was 96.1\% $(n=122)$ in TDF-containing group and $95.6 \%(n$ $=110$ ) in non-TDF-containing group (Table 1).

No significant difference of virological characteristics between two groups (Table 1). Serum HBV-DNA level in TDF-containing group and non-TDF-containing 
Table 1 Baseline characteristics of CHB-related compensated cirrhosis

\begin{tabular}{|c|c|c|c|}
\hline & $\begin{array}{l}\text { TDF-containing } \\
(n=127)\end{array}$ & $\begin{array}{l}\text { Non-TDF-containing } \\
(n=115)\end{array}$ & $p$-value \\
\hline Age, $($ mean $\pm S D)$ & $50 \pm 12$ & $50 \pm 10$ & 0.62 \\
\hline Gender & & & 0.28 \\
\hline Male & $114(89.8 \%)$ & $98(85.2 \%)$ & \\
\hline Female & $13(12.4 \%)$ & $17(9.7 \%)$ & \\
\hline $\begin{array}{l}\text { HBV DNA }(\log 10 \\
\text { copy } / m L \text {, mean } \pm \text { SD) }\end{array}$ & $3.93 \pm 1.31$ & $3.88 \pm 1.18$ & 0.76 \\
\hline HBeAg & & & 0.92 \\
\hline Positive & $92(72.4 \%)$ & $84(73.0 \%)$ & \\
\hline Negative & 35 (27.6\%) & $31(27.0 \%)$ & \\
\hline $\operatorname{ALT}(\mathrm{U} / \mathrm{L}$, mean $\pm \mathrm{SD})$ & $98.3 \pm 23.6$ & $96.3 \pm 24.4$ & 0.34 \\
\hline $\begin{array}{l}\text { Total bilirubin ( } \mu \mathrm{mol} / \mathrm{L}) \text {, } \\
\text { median (range) }\end{array}$ & $16.1(5.7-65.0)$ & $14.4(5.5-39.8)$ & 0.11 \\
\hline $\begin{array}{l}\text { ALB (g/L), median } \\
\text { (range) }\end{array}$ & $4.1(3.7-5.9)$ & $4.0(2.8-6.0)$ & 0.19 \\
\hline $\begin{array}{l}\text { AFP, ng/mL, } \\
\text { median (range) }\end{array}$ & $2.91(1.21-34)$ & $3.11(1.36-21)$ & 0.06 \\
\hline $\begin{array}{l}\mathrm{PLT}, 10 \wedge 9 / \mathrm{L} \\
\text { median (range) }\end{array}$ & $197.33(99-252)$ & $184.31(108-239)$ & 0.08 \\
\hline Child-Pugh score & & & 0.87 \\
\hline A & $122(96.1 \%)$ & $110(95.6 \%)$ & \\
\hline B & $5(3.9 \%)$ & $5(4.4 \%)$ & \\
\hline
\end{tabular}

group were $3.93 \pm 1.31(\log 10 \mathrm{copy} / \mathrm{mL}$, mean $\pm \mathrm{SD})$ and $3.88 \pm 1.18(\log 10$ copy $/ \mathrm{mL}$, mean $\pm \mathrm{SD})$, respectively. The percentage of $\mathrm{HBe}$ antigen were $72.4 \%(n=92)$ in TDF-containing group and $73.0 \%(n=84)$ in nonTDF-containing group. $37 \% \quad(n=47)$ patients in TDF-containing group and $26.9 \%(n=31)$ in non-TDF containing group were $\mathrm{HBe}$ antibody positive. Thirteen patients in TDF-containing group and 9 patients in non-TDF containing group were HBsAg negative.

\section{Virological, serological and biochemical response}

All patients achieved virological response by 48 weeks after NAs regimens treatment (HBV DNA $<1000$ copies $/ \mathrm{mL}$ ). Eleven patients receiving LAM and 12 patients receiving Ldt in non-TDF-containing group were switched to receiving ETV by 24 weeks. Thirty-two patients in TDF-containing group and 16 patients in non-TDF-containing group experienced virological breakthrough due to poor compliance (HBV DNA > 1000 copies $/ \mathrm{mL}) .64 .1 \%$ patients $(n=59)$ achieved $\mathrm{HBeAg}$ seroconversion in TDF-containing group and $51.2 \%$ patients $(n=43)$ in non-TDF containing group. All patients achieved ALT normalization by 96 weeks.

\section{The development of HCC}

Overall, $14.5 \%$ patients $(n=35)$ developed HCC during follow up. $11.0 \%$ patients $(n=14)$ in TDF-containing and $18.3 \%$ patients $(n=21)$ in non-TDF-containing group developed HCC. 5-year cumulative rate of HCC development in all patients were $26.7 \%$. The cumulative probability of HCC development in TDF-containing group was significantly lower than it in non-TDFcontaining group (hazard ratio, 0.18; 95\% confidence interval range, $0.07-0.45, p<0.05$ ) (Fig. 1). In order to identify the potential factors related to the probability of HCC development, we also conduct univariant and multi-variant analysis to investigate the association between baseline characteristics and HCC development. Univariant and multi-variant analysis indicated that TDF-containing regimen treatment was independently associated with lower HCC development rate (hazard ratio, 0.18; 95\% confidence interval range, 0.07-0.45, $p<0.05$ ) (Table 2).

\section{Discussion}

Our study demonstrated that anti-virus regimen containing TDF provide a lower probability of HCC development than regimen without TDF in $\mathrm{CHB}$ related
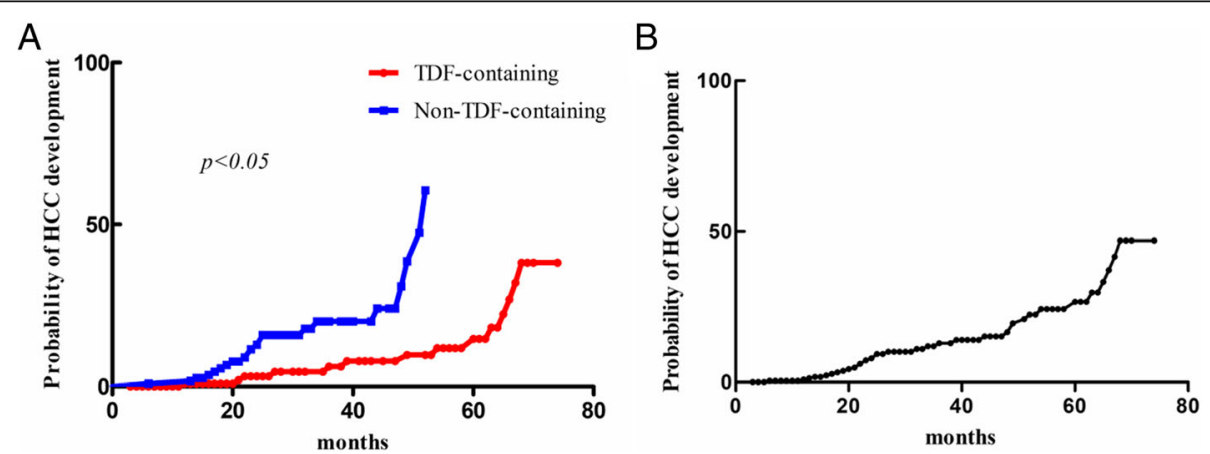

Fig. 1 The cumulative probability of HCC development. a the comparison of cumulative HCC development probability between TDF-containing group (red) and non-TDF-containing group (blue). X-axis represented time (month), Y-axis represented probability of HCC development. b the cumulative probability of HCC development 
Table 2 Univariate and multivariate analysis of baseline characteristics with HCC development

\begin{tabular}{llll}
\hline & Univariant analysis & $p$-value & Multivariant analysis \\
& HR $(95 \% \mathrm{Cl})$ & $\mathrm{HR}(95 \% \mathrm{Cl})$ \\
\hline Age & $1.00(0.99-1.01)$ & $\mathrm{NS}$ & \\
Gender:male/female & $3.11(0.99-9.72)$ & $\mathrm{NS}$ & \\
Child-Pugh score: A/B & $0.48(0.21-1.10)$ & $<0.05$ & $0.18(0.07-0.45)$ \\
ADV-containing/Non-ADV-treatment & $0.18(0.09-0.43)$ & $\mathrm{NS}$ & $<0.05$ \\
Total bilirubin: $<24 / \geq 24(\mu \mathrm{mol} / \mathrm{L})$ & $0.52(0.19-1.41)$ & $\mathrm{NS}$ & \\
HBV DNA: $<4 / \geq 4$ (log10 copies/mL) & $0.85(0.41-1.76)$ & $\mathrm{NS}$ & \\
HBeAg: Positive/negative & $1.16(0.54-2.50)$ & &
\end{tabular}

HBeAg hepatitis B e antigen

compensated cirrhosis patients. It has been determined that sustained suppression of HBV replication is fundamental for $\mathrm{CHB}$ patients and delays hepatic diseases progression to end stage liver diseases, such as decompensated cirrhosis and HCC [31, 32]. However, regarding the access to anti-virus agents, what kind of treatment is suitable for patients with cirrhosis is not determined. Our study provided evidence for appropriated anti-virus treatment to management of $\mathrm{CHB}$ related compensated cirrhosis patients.

Recent studies revealed that nucleutide analogue rather than nucleoside analogue provide additional effect to induce expression of interferon- $\lambda 3$ [29], since interferon- $\lambda 3$ has been demonstrated to be involved in modulation of imunity during virus infection or autoimune diseases [33]. Inflammation is determined to have a strong association with carcinogenesis and recurrence of HCC [34]. In our study cumulative probability of HCC development in TDF containing group is significantly lower than non-TDF containing group, which might be caused by hypothesis above. But the mechanism requires further clinical evidence.

The main flaw in our study is the limitation to serum HBV marker quantification, which might reveal the potential mechanism of our outcomes. The association between nucleotide analogues treatment and $\mathrm{HBsAg}$ reduction have been proved [29], as well as the relationship between HCC and HBsAg [35]. As a retrospective study, the bias in data collection and poor compliance of patients also limit further analysis for majority of patients included in our study received anti-virus treatment outside of hospital. Thus, a prospective randomized clinical trial to compare anti-virus regimens can provide a better analysis and solid evidence.

\section{Conclusion}

Both anti-virus regimens provided benefit for the prognosis of $\mathrm{CHB}$ related compensated cirrhosis patients. Regimen containing TDF, alone or in combination with other agents, lower the incidence of HCC development in $\mathrm{CHB}$ patients with compensated cirrhosis.

\section{Abbreviations}

ALT: alanine aminotransferase; CHB: chronic hepatits B; ETV: entecavir; HBeAg: hepatitis B e antigen; HBsAg: hepatits B surface antigen; HBV: hepatitis B virus; HCC: hepatocellular carcinoma; LAM: lamivudine; LdT: telbivudine; NAs: Nucleus(t)ide analogues; SD: standard deviation;

TDF: Tenofovir disoproxil fumarate

Availability of data and materials

Please contact author for data requests.

\section{Authors' contributions}

PZ and QL contribute to patients follow-up, data collection and manuscript preparation. MY is responsible for patients follow-up. XW is responsible for study design, statistical analysis and patients follow-up. All authors read and approved the final manuscript.

\section{Ethics approval and consent to participate}

This study was conducted under compliance with the Declaration of Helsinki and were approved by sixth people's hospital of Qingdao.

\section{Consent for publication}

Not applicable.

\section{Competing interests}

The authors declare that they have no competing interests.

\section{Publisher's Note}

Springer Nature remains neutral with regard to jurisdictional claims in published maps and institutional affiliations.

Received: 6 June 2018 Accepted: 20 August 2018

Published online: 29 August 2018

\section{References}

1. Jemal A, Bray F, Center MM, Ferlay J, Ward E, Forman D. Global cancer statistics. CA Cancer J Clin. 2011;61(2):69-90.

2. Wei KR, Yu X, Zheng RS, Peng XB, Zhang SW, Ji MF, Liang ZH, Ou ZX, Chen WQ. Incidence and mortality of liver cancer in China, 2010. Chin J Cancer. 2014;33(8):388-94

3. Zheng R, Zeng H, Zhang S, Chen W. Estimates of cancer incidence and mortality in China, 2013. Chin J Cancer. 2017;36(1):66.

4. Ding J, Wang H. Multiple interactive factors in hepatocarcinogenesis. Cancer Lett. 2014;346(1):17-23.

5. Singal AG, El-Serag HB. Hepatocellular carcinoma from epidemiology to prevention: translating knowledge into practice. Clin Gastroenterol Hepatol. 2015;13(12):2140-51.

6. El-Serag HB. Hepatocellular carcinoma. N Engl J Med. 2011;365(12):1118-27.

7. Hiraoka A, Kawamura T, Aibiki T, Okudaira T, Toshimori A, Yamago H, Nakahara H, Suga Y, Azemoto N, Miyata H, et al. Prognosis and therapy for ruptured hepatocellular carcinoma: problems with staging and treatment strategy. Eur J Radiol. 2015;84(3):366-71.

8. Kawamura Y, Arase Y, Ikeda K, Akuta N, Kobayashi M, Saitoh S, Suzuki F, Suzuki $Y$, Inao M, Mochida S, et al. Effects of alcohol consumption on 
Hepatocarcinogenesis in Japanese patients with fatty liver disease. Clin Gastroenterol Hepatol. 2016;14(4):597-605.

9. Petruzziello A. Epidemiology of hepatitis B virus ( $\mathrm{HBV}$ ) and hepatitis $C$ virus (HCV) related hepatocellular carcinoma. Open Virol J. 2018;12:26-32.

10. Romeo R, Petruzziello A. Hepatitis delta virus and hepatocellular carcinoma: an update, vol. 2018. p. 1-7.

11. Stroffolini T, Sagnelli E, Rapicetta M, Felaco FM, Filippini P, Annella T, Petruzziello A, Chionne P, Sarrecchia B, Piccinino F, et al. Hepatitis B virus DNA in chronic HBsAg carriers: correlation with HBeAg/anti-HBe status, antiHD and liver histology. Hepato-Gastroenterology. 1992;39(1):62-5.

12. Sagnelli E, Felaco FM, Rapicetta M, Stroffolini T, Petruzziello A, Annella T, Chionne $P$, Pasquale G, Filippini P, Peinetti $P$, et al. Interaction between HDV and HBV infection in HBsAg-chronic carriers. Infection. 1991;19(3):155-8.

13. Tanaka M, Katayama F, Kato H, Tanaka H, Wang J, Qiao YL, Inoue M. Hepatitis B and $C$ virus infection and hepatocellular carcinoma in China: a review of epidemiology and control measures. J Epidemiol. 2011;21(6):401-16.

14. Ott JJ, Stevens GA, Groeger J, Wiersma ST. Global epidemiology of hepatitis $B$ virus infection: new estimates of age-specific HBsAg seroprevalence and endemicity. Vaccine. 2012;30(12):2212-9.

15. Iloeje UH, Yang HI, Su J, Jen CL, You SL, Chen CJ. Predicting cirrhosis risk based on the level of circulating hepatitis B viral load. Gastroenterology. 2006;130(3):678-86.

16. Chen CJ, Yang HI, Su J, Jen CL, You SL, Lu SN, Huang GT, Iloeje UH. Risk of hepatocellular carcinoma across a biological gradient of serum hepatitis $B$ virus DNA level. Jama. 2006;295(1):65-73.

17. Iloeje UH, Yang HI, Jen CL, Su J, Wang LY, You SL, Chen CJ. Risk and predictors of mortality associated with chronic hepatitis B infection. Clin Gastroenterol Hepatol. 2007;5(8):921-31.

18. Wang Y, Xiang X, Chen L, Cao Z, Bao R, Zhou H, Tang W, Lu J, Lin L, Xie Q, et al. Randomized clinical trial: Nucleos(t)ide analogues improved survival of CHB-related HCC patients via reducing severity and progression of malignancy. Oncotarget. 2016;7(36):58553-62.

19. Kurokawa M, Hiramatsu N, Oze T, Yakushijin T, Miyazaki M, Hosui A, Miyagi T, Yoshida $Y$, Ishida $H$, Tatsumi $T$, et al. Long-term effect of lamivudine treatment on the incidence of hepatocellular carcinoma in patients with hepatitis B virus infection. J Gastroenterol. 2012;47(5):577-85.

20. EASL 2017 Clinical Practice Guidelines on the management of hepatitis B virus infection. J Hepatol. 2017;67(2):370-98. PMID 28427875

21. Hosaka T, Suzuki F, Kobayashi M, Seko Y, Kawamura Y, Sezaki H, Akuta N, Suzuki Y, Saitoh S, Arase Y, et al. Long-term entecavir treatment reduces hepatocellular carcinoma incidence in patients with hepatitis $B$ virus infection. Hepatology (Baltimore, Md). 2013;58(1):98-107.

22. Wang JP, Kao FY, Wu CY, Hung YP, Chao Y, Chou YJ, Li CP. Nucleos(t)ide analogues associated with a reduced risk of hepatocellular carcinoma in hepatitis B patients: a population-based cohort study. Cancer. 2015;121(9): $1446-55$.

23. Wu CY, Lin JT, Ho HJ, Su CW, Lee TY, Wang SY, Wu C, Wu JC: Association of nucleos(t)ide analogue therapy with reduced risk of hepatocellular carcinoma in patients with chronic hepatitis B: a nationwide cohort study. Gastroenterology 2014, 147(1):143-151.e145

24. Ma KW, Cheung TT. Surgical resection of localized hepatocellular carcinoma: patient selection and special consideration. J Hepatocell Carcinoma. 2017;4:1-9.

25. Wu JC, Huang YH, Chau GY, Su CW, Lai CR, Lee PC, Huo TI, Sheen IJ, Lee SD, Lui WY. Risk factors for early and late recurrence in hepatitis B-related hepatocellular carcinoma. J Hepatol. 2009;51(5):890-7.

26. Wu CY, Chen YJ, Ho HJ, Hsu YC, Kuo KN, Wu MS, Lin JT. Association between nucleoside analogues and risk of hepatitis B virus-related hepatocellular carcinoma recurrence following liver resection. Jama. 2012;308(18):1906-14.

27. Hann HW, Coben R, Brown D, Needleman L, Rosato E, Min A, Hann RS, Park KB, Dunn S, DiMarino AJ. A long-term study of the effects of antiviral therapy on survival of patients with HBV-associated hepatocellular carcinoma (HCC) following local tumor ablation. Cancer Med. 2014;3(2):390-6.

28. Chan AC, Chok KS, Yuen WK, Chan SC, Poon RT, Lo CM, Fan ST. Impact of antiviral therapy on the survival of patients after major hepatectomy for hepatitis B virus-related hepatocellular carcinoma. Arch Surg (Chicago, III : 1960). 2011;146(6):675-81.

29. Murata K, Asano M, Matsumoto A, Sugiyama M, Nishida N, Tanaka E, Inoue T, Sakamoto M, Enomoto N, Shirasaki T, et al. Induction of IFN-lambda3 as an additional effect of nucleotide, not nucleoside, analogues: a new potential target for HBV infection. Gut. 2016;
30. Pugh RN, Murray-Lyon IM, Dawson JL, Pietroni MC, Williams R. Transection of the oesophagus for bleeding oesophageal varices. Br J Surg. 1973;60(8):646-9.

31. Tawada A, Kanda T, Imazeki F, Yokosuka O. Prevention of hepatitis B virusassociated liver diseases by antiviral therapy. Hepatol Int. 2016;10(4):574-93.

32. Parikh $P$, Ryan JD, Tsochatzis EA. Fibrosis assessment in patients with chronic hepatitis B virus (HBV) infection. Ann Transl Med. 2017:5(3):40.

33. Syedbasha M, Egli A. Interferon lambda: modulating immunity in infectious diseases. Front Immunol. 2017:8:119.

34. Sia D, Villanueva A, Friedman SL, Llovet JM. Liver Cancer cell of origin, molecular class, and effects on patient prognosis. Gastroenterology. 2017; 152(4):745-61.

35. Ringelhan $M, O^{\prime}$ Connor $T$, Protzer $U$, Heikenwalder $M$. The direct and indirect roles of HBV in liver cancer: prospective markers for HCC screening and potential therapeutic targets. J Pathol. 2015;235(2):355-67.

\section{Ready to submit your research? Choose BMC and benefit from:}

- fast, convenient online submission

- thorough peer review by experienced researchers in your field

- rapid publication on acceptance

- support for research data, including large and complex data types

- gold Open Access which fosters wider collaboration and increased citations

- maximum visibility for your research: over $100 \mathrm{M}$ website views per year

At $\mathrm{BMC}$, research is always in progress.

Learn more biomedcentral.com/submissions 